\title{
CHLORPROPAMIDE-ALCOHOL FLUSHING IN NON INSULINDEPENDENT DIABETES: PREVALENCE OF SMALL AND LARGE VESSEL DISEASE AND OF RISK FACTORS FOR ANGIOPATHY
}

\author{
Piero Micossi * Pier Mannuccio Mannucci ${ }^{\circ}$ \\ Maria Cristina Librenti * UMberto RagGi * \\ Armando D'Angelo o Sandro Corallo *: Barbara Garimberti * \\ SANDRO BOZZINI ${ }^{\circ}$ ETTORE MALACCO ** \\ Clinica Medica WIII. Ospedales Raffarle. Mitani* * \\ Ospetalt L. Sacco, Milano ** \\ Centro per lEmufilia e la Trombosi 'Angelo Bianchi Bonumi: Liniversità di Milano. \\ Clinica Oculistica I, Eniversità di Milano
}

Chlorpropamide-alcohol flushing (CPAF) has been reported to be associated with a low prevalence of large and small vessel disease in non insulin. dependent diabetics ${ }^{3.19,20}$. However, the specificity of the flushing test has re. cently been questioned ${ }^{17.22}$, and the occurrence of the CPAF phenomenon varies considerably in different diabetic clinics ${ }^{3,12,17,14,20,22}$.

We have studied the CPAF phenomenon in 108 non insulin dependent diabetics and have investigated several so-called 'risk factors' for vessel disease (blood pressure, serum lipids and hemostatic parameters), to ascertain whether an uneven distribution of lesions might be related to metabolic or hemostatic abnormalities.

\section{PATIENTS AND METHODS}

One hundred and eight non insulin-dependent diabetics diagnosed according to the criteria of the National Diabetes Data Group ${ }^{23}$ (56 females and 52 males, mean age 56 years, range 32.81 ) were asked to take a $250 \cdot \mathrm{mg}$ chlorpropamide tablet in the evening, $12 \mathrm{~h}$ before the test and fast until the following morning, when they came to the clinic and drank $40 \mathrm{ml}$ of sherry (Tio Pepe). Facial temperature was measured immediately before sherry ad.

Key-words: Chlorpropamide-alcohol flushing; Complications of diabetes; Risk factors.

Received: June 4,1981.

Acta diabet. lat. 19, 141, 1982. 
ministration and 20 min later, using two small sensor probes fixed by adhesive tape over the forehead and the lateral canthus of the eye, and a digital thermometer for registration. The test was positive if facial flush appeared and there was a sensation of warmth of the face and neck. The mean tem. perature increases in positive patients were $1.4{ }^{\circ} \mathrm{C} \pm 0.85$ (SD) and $0.4^{\circ} \mathrm{C} \pm 0.15(\mathrm{SD})$ in negative patients. The room temperature was constant at $17^{\circ} \mathrm{C}$ (experiments were performed in a fully condicioned area), and the patients were kept waiting $1 \mathrm{~h}$ before drinking the sherry.

All the positive patients repeated the alcohol test three months later, with placebo given instead of chlorpropamide.

Clinical findings. The eyes of the 108 patients were examined independently through dilated pupils by two expert ophthalmologists unaware of their status as flushers. Patients with no retinal lesions or with fewer than 5 exudates or hemorrhages are pooled together in the nil/minimal group; pa. tients with proliferative retinopathy are not considered separately, as there are too few of them". Patients with severe retinopathy (more than 5 lesions in at least one eye) are subdivided on the basis of presence or absence of important visual loss (more than 50\%, objectively measured) due to diabetic maculopathy.

Standard electrocardiography was performed: the presence of more than 3 extrasystoles over a 2 -min registration, the presence of atrial fibrillation, the presence of left or right bundle branch block, the presence of an atrioventricular conduction time equal or greater than $0.21 \mathrm{sec}$, were considered pathological findings and pooled together in the 'rhythm or conduction de. fects'; patients with classical findings of previous myocardial infarction ${ }^{12}$ or showing a J-point depression of the S.T segment greater than $1.0 \mathrm{~mm}$ or a J. point elevation greater than $1 \mathrm{~mm}$ were considered ischemic; the lowering or flattening of the $\mathrm{T}$ wave with normal S.T segment were not considered as myocardial ischemia whereas the $T$-wave inversion even if not accompanied by S-T segment alterations was considered a sign of ischemia.

Oscillography was also performed in our subjects at both calves. The findings were classified as abnormal according to the following criteria. A maximal wave amplitude smaller than $5 \mathrm{~mm}$, a maximal wave amplitude re. duction in one leg compared to the other of more than $50 \%$ were considered to be reduced pulses, whereas the absence of wave was classified as abolished pulse.

Blood pressure was measured at the time of the first alcohol challenge, after $3 \mathrm{~min}$ in the supine position: systolic blood pressure was taken at the furst Korotkoffs sound and diastolic blood pressure at the fourth Korotkoffs sound.

Blood sampling . One week after the first alcohol test, the patients came back to the clinic after an overnight fast; a blood sample was drawn through a 19 gauge needle for lipid and hemostasis assays.

Lipid determinations. Serum cholesterol was measured by the enzymatic method of BABSON et al. ${ }^{2}$, serum triglycerides by the method of EGGSTEIN", serum HDL cholesterol with phosphotungstate precipitation method of Burnstein et al. s. 
Hemostatic variables . Factor VIII coagulant activity (VIII:C) was assayed in citrated plasma by a two-stage method ${ }^{*}$ and factor VIII-related antigen (VIII $\mathrm{R}: \mathrm{Ag}$ ) by quantitative immunoelectrophoresis ${ }^{18}$ using a monospecific antiserum to human Factor VIII/von Willebrandt Factor from rabbit (Istituto Behr. ing, Scoppito/L'Aquila, Italy). The results were expressed as percentage of plasma pooled from 30 normal subjects, snapped frozen and stored at $-70^{\circ} \mathrm{C}$.

Plasma fibrinogen was determined by the method of VERMYLEN et al. ${ }^{26}$ and values are expressed in $\mathrm{g} / \mathrm{dl}$. For plasma $\beta$-thromboglobulin ( $\beta$.TG) measurement $2.7 \mathrm{ml}$ of venous blood were immediately transferred into plastic tubes placed on crushed ice and mixed with $0.3 \mathrm{ml}$ of an antiplatelet anticoagulant freshly prepared by adding $10 \mu \mathrm{g}$ of prostaglandin $\mathrm{E}_{\mathrm{i}}$ and $50 \mathrm{mg}$ of theophylline to $10 \mathrm{ml}$ of $10 \%$ EDTA* $\beta$-TG was measured in platelet poor plasma by radioimmunoassay using a commercial kit (Radiochemical Center, Amersham, U.K.), and the values expressed as $\mathrm{ng} / \mathrm{ml}$.

Glycosylated hemoglobin ( $\mathrm{HbAl}$ ) was measured using a commercial kit (Fast Hemoglobin Test System. Isolab Inc, Akron/O. U.S.A.) which pools together fractions HbAl $(a+b+c)$.

Statistical analysis was done by the $\chi^{2}$-test and the standard Student's $t$. test for unpaired data.

\section{RESULTS}

Table 1 shows the CPAF-positive and negative patients (numbers and percentages). Patients who had positive alcohol test after placebo administration, are considered aspecific flushers (AF), whereas those who had positive

\begin{tabular}{|c|c|c|c|c|}
\hline & $\begin{array}{l}\text { CPAF-positive } \\
\text { (irue Aushers) }\end{array}$ & $\begin{array}{l}\text { CPAF-negative } \\
\text { (non flushers) }\end{array}$ & $\begin{array}{c}A F \\
\text { (aspecific } \\
\text { flushers) }\end{array}$ & $\begin{array}{c}\text { total flushers } \\
\text { (CPAF-yositive } \\
\text { plus AF) }\end{array}$ \\
\hline total number (\%) & $19(17 \%)$ & $73(68 \%)$ & $16(15 \%)$ & $35(32 \%)$ \\
\hline men & $4(21 \%)$ & $43(590 \%)$ & $5(31 \%)$ & $9(26 \%)$ \\
\hline women & $15\langle 79 \%$ & $30(410)$ & $11\left(69^{n}(n)\right.$ & $26(7+\%)$ \\
\hline \multicolumn{5}{|l|}{ type of reatment } \\
\hline - diet alone & $10\langle 53 \%\}$ & $26(60 \%)$ & $1(6 \%)$ & $11(31 \%)$ \\
\hline - oral agents & $9(47 \%)$ & $47(40 \%)$ & $15(94 \%)$ & $24(69 \%)$ \\
\hline $\begin{array}{l}\text { presence of family } \\
\text { history of diaberes }\end{array}$ & $9(47 \%)$ & $30(41 \%)$ & $8(50 \%)$ & $17(49 \%)$ \\
\hline \multicolumn{5}{|l|}{$\begin{array}{l}\text { duration of diabeies } \\
\text { (vears, mean } \pm \text { SD }\end{array}$} \\
\hline- toral & $5.0 \pm 4.1$ & $7.4 \pm 6.1$ & $9.2 \pm 5.4$ & $6.5 \pm 5.9$ \\
\hline - women & 4.92 & 7.4 & 9.6 & 6.9 \\
\hline
\end{tabular}

" the percentage of women is significantly increased in flushers (both AF and CPAF positive) ( $p<0.02$ )

Tab. 1. General characteristics of the 108 non insulin dependent diabetics, divided according to their flushing status. 
alcohol test after chlorpropamide administration and negative test after placebo, are indicated as CPAF-positive patients.

Of 35 flushers in the first test, $16(46 \%)$ were aspecific and $19(54 \%)$ were 'true' flushers. The percentage of women is significantly higher in the CPAFpositive and in the AF group $(p<0.02)$, suggesting that flushing phenomena may be sex-linked. The presence of a family history of diabetes was equally distributed in all the groups.

The mean duration of diabetes did not significantly differ among groups, even though it was slightly shorter for the 'true' flushers and slightly longer for the AF than for the CPAF-negative patients. Table 1 also shows that the occurrence of 'true' flushing was similar in the diabetics treated by diet alone and in those treated with oral agents. By contrast, almost all of the aspecific flushers had been on long-term treatment with oral agents.

Table 2 shows the prevalence of vascular lesions. Even though CPAF. negative and AF showed a slightly higher prevalence of severe lesions with visual loss there was no significant difference between the groups. Unlike CPAF-negative and AF, none of the CPAF-positive patients showed loss of visual acuity due to maculopathy in spite of the fact that $16 \%$ of them had more than five retinal lesions.

\begin{tabular}{|c|c|c|c|c|}
\hline & $\begin{array}{l}\text { CPAF positive } \\
\text { \{rue flushers\} }\end{array}$ & $\begin{array}{l}\text { CPAF-negative } \\
\text { (non thushers) }\end{array}$ & $\begin{array}{c}\text { AF } \\
\text { (aspecific } \\
\text { flushers) }\end{array}$ & $\begin{array}{c}\text { roral flushers } \\
\text { (CPAF positive } \\
\text { plus AF) }\end{array}$ \\
\hline \multicolumn{5}{|l|}{ retinopathy } \\
\hline nil/minimal & $16(84 \%)$ & $67(93 \%)$ & $11(69 \%)$ & $27(78 \%)$ \\
\hline severe, no visual loss & $3(16 \%)$ & $2(3 \%)$ & $1(6 \%)$ & $4(11 \%)$ \\
\hline severe, visual loss & $0\left(0^{*} \%\right)$ & $4(5 \%)$ & $4\left(25^{10 / 11}\right)$ & $4(11 \%)$ \\
\hline electrocardingram * & & & & \\
\hline $\begin{array}{l}\text { normal } \\
\text { abnormal }\end{array}$ & $14(73 \%(4)$ & $39(54 \%)$ & $9(50 \%)$ & $22(63 \%)$ \\
\hline - rhythm or conduction defects & $.5(27 \%)$ & $25\langle 34 \%\}$ & $5(31 \%)$ & $10(28 \%)$ \\
\hline - perfusion alteration & $0(0 \%)$ & $9(12 \%)$ & $3\{1904$ & $3(9 \%)$ \\
\hline \multicolumn{5}{|l|}{ oscillography** } \\
\hline $\begin{array}{l}\text { normal } \\
\text { abnormal }\end{array}$ & $14(74 \%)$ & $38(52 \% 0)$ & $6(37 \%)$ & $20(57 \%)$ \\
\hline - reduced & $4(21 \%)$ & $26(36 \%)$ & $7(1 .+\%)$ & $11(32 \%)$ \\
\hline - abolished & $1(5 \%)$ & $9(12 \%)$ & $3(1944)$ & $4(11 \%)$ \\
\hline
\end{tabular}

"the prevalence of normal electrocardiograms is significantly higher in 'true' flushers than in $A F$ and CPAF-negative patients $(p<0.001$ )

** the prevalence of normal oscillograms is significantly higher in 'true' flushers than in $A F(p<0.002)$ and CPAF-negative patients $(p<0.005$ )

Tab. 2 - Distribution of retinopathy, electrocardiographic and oscillographic abnormalities in CPAF-positive, aspecific flushers (AF), non-flushers (CPAF-negative) and pooled flushers. Men and women pooled together. 


\begin{tabular}{|c|c|c|c|}
\hline & $\begin{array}{l}\text { CPAF prositive } \\
\text { (true flushers }\end{array}$ & $\begin{array}{l}\text { CPAF-negative } \\
\text { (nonflushers) }\end{array}$ & $\frac{A F}{\text { (aspecific tushers) }}$ \\
\hline$S B P$ inmHg) & $15.5 \pm 97$ & $150 \pm 20$ & $164 \pm 33$ \\
\hline $\mathrm{DBP}(\mathrm{mm} H \mathrm{~g})$ & $88 \pm 14$ & $88 \pm 12$ & $90 \pm 16$ \\
\hline $\mathrm{TG}$ (ing/d) & $137 \pm .57$ & $150 \pm 96$ & $144 \pm 73$ \\
\hline $\mathrm{CHOL}(\mathrm{mg} / \mathrm{d})$ & $277 \pm 47$ & $26.5 \pm 59$ & $271 \pm 66$ \\
\hline $\mathrm{HDL} \cdot \mathrm{CHOL}(\mathrm{mg} / \mathrm{dl})$ & $38 \pm 16$ & $50 \pm 16$ & $59 \pm 15$ \\
\hline VIIl:C & $122 \pm 32$ & $116=31$ & $126 \pm 42$ \\
\hline VIIR:Ag $(\%)$ & $157 \pm 54$ & $181 \pm 75$ & $161 \pm 63$ \\
\hline fibrinogen $(\mathrm{g} / \mathrm{d}$ il $)$ & $0.29=0.07$ & $0.31=0.09$ & $0.32 \pm 0.06$ \\
\hline$\beta-T G(n g / m l)$ & $34.3 \pm 36.1$ & $32.2 \geq 31.7$ & $30.1 \pm 27.4$ \\
\hline
\end{tabular}

Tab. 3 - Blood pressure, serum lipids and hemostatic variables. The ralues shown are means $\pm \mathrm{SD} . \mathrm{SBP}=$ svstolic blood pressure; $\mathrm{DBP}=$ diastolic blood pressure: $\mathrm{TG}=$ serum triglv cerides; $\mathrm{CHOL}=$ total serum cholesterol; HDL.CHOL = serum HDL cholesterol; VIII:C $=$ Factor VIII coagulant activity; VIIR: $\mathrm{Ag}=$ factor VIll-related antigen; $B$-TC $=\beta$-thromboglobulin.

ECG abnormalities were separated into rhythm or conduction defects, and perfusion defects (ischemia or previous myocardial infarction). Normal electrocardiograms were found significantly more frequently in the CPAF. positive group than either the AF or CPAF-negative patients $(p<0.001)$. None of the 'true' flushers showed perfusion defects.

Seventy.four percent of the 'true' flushers had normal leg oscillograms, compared to the $52 \%$ in the CPAF-negative group $(p<0.005)$ and $37 \%$ in the AF group $(p<0.002)$. Only one of 19 patients $(5 \%)$ lacked a peripheral pulse in the CPAF-positive group, compared with 9 of $73(12 \%)$ in the CPAF. negative group.

Table 3 lists the values for other parameters studied in relation to the CPAF test. We did not observe any significant differences among the patient groups in systolic and diastolic blood pressure, total and HDL-cholesterol, triglycerides, VIII:C, VIIIR:Ag, plasma B.TG or fibrinogen.

As far as metabolic control is concerned, the 'true' flushers showed a mean value of $\mathrm{HbAl}$ of $9.06 \pm 0.67 \% \mathrm{SEM}$, the CPAF-negative subjects of $9.09 \pm 0.38 \%$ SEM, the AF of $9.8 \pm 1.08 \%$ SEM. The differences among groups are not significant.

Table 4 showed the prevalence of lesions when considering women se. parately. In the CPAF positive group the prevalence of women with nil/mini. mal retinal damage is very close to that observed in tab. 2 for the pooled data $(86 \%$ us $84 \%)$, and the same thing happens for normal electrocardiograms $(73 \%$ vs $73 \%)$ and oscillograms $(74 \%$ is $73 \%)$.

\section{DISCUSSION}

CPAF has been reported to be a dominantly inherited trait in non insulin-dependent diabetics, associated with low prevalence of retinal, heart and peripheral arterial lesions ${ }^{3.2 n}$. Recently, however, the specificity and the signi. ficance of the phenomenon have been questioned, since many positive re. 
sponses to the CPAF-test have been found in normal subjects and in insulindependent diabetics". Moreover, in different diabetic clinics, testing diabetics for $\mathrm{CPAF}$ has led to a wide range of results 17.19 .20 .22 . In this series of 108 noninsulin-dependent out-patient diabetics, the total prevalence of flushers was $32 \%$, but almost half of those $(46 \%)$ were aspecific flushers, in that they also flushed drinking alcohol after placebo. The percentage of 'true' flushers (17\%) is therefore much lower than that reported either by Lesue et al. ${ }^{20}(66 \%)$ or by FitzGerald et al. ${ }^{12}$ (33\%). The high prevalence of maturity onset diabetes of the young ('Mason type' diabetes) in the population studied by PYKE ${ }^{24}$ might at least partially account for his higher number of CPAF-positive patients. FitzGerald et al. ${ }^{12}$ did not test the flushers with placebo, so their positive cases might well include a number of aspecific flushers. It cannot be ruled out, however, that there are true differences in the incidence of the phenomenon, related to the different genetic backgrounds of the patients.

The importance of distinguishing CPAF-positive patients from aspecific flushers is emphasized by the different prevalences of vascular lesions found in our series of diabetics than in previous reports ${ }^{1220}$. When the patients who flushed with alcohol after chlorpropamide and those who also flushed after placebo were considered together, the prevalence of lesions in both large and small vessels was similar to that of non-flushers. However, when the aspecific flushers were eliminated and the prevalence of lesions was evaluated in the 'true' flushers, they had no loss of visual acuity due to diabetic ma.

\begin{tabular}{|c|c|c|c|}
\hline & CPAF-positive & CPAF negative & $A F$ \\
\hline \multicolumn{4}{|l|}{ retinupathy } \\
\hline nil/minimal & $13(86 \%)$ & $26(87 \%)$ & $9(82 \%)$ \\
\hline severe, no visual loss & $2(1+\%)$ & $13 \%$ & $1(9 \%)$ \\
\hline severe, visual loss & $0\left(0^{\mathrm{w}}\right)$ & $3110 \% \%$ & $1(9 \%)$ \\
\hline \multicolumn{4}{|l|}{ electrocardiogram } \\
\hline normal & $11(7.3 \%)$ & $1.3(1+4 \%)$ & $4(36 \%)$ \\
\hline \multicolumn{4}{|l|}{ abnormal } \\
\hline - rhythm or conduction defecrs & $4(27 \%)$ & $12\{40 \%\}$ & $4(36 \%)$ \\
\hline - perfusion altevation & $0(0 \%)$ & $5(169)$ & $3\left(2 x^{0}, 1 i\right]$ \\
\hline \multicolumn{4}{|l|}{ oscillography } \\
\hline normal & $11(73 \%)$ & $15(50 \%)$ & $4(36 \%)$ \\
\hline \multicolumn{4}{|l|}{ abnormal } \\
\hline - reduced & $3(20 \%)$ & $10(3.3 \%)$ & $4(36 \%)$ \\
\hline - abolished & $1(7 \%)$ & $5(17 \%$ & $3(28 \%)$ \\
\hline
\end{tabular}

Tab. 4- Distribution of retinopathy, ECG and oscillographic lesions in CPAF positive, aspecific flushers (AF), non flushers (CPAF-negative) in women considered separately. The prevalence of lesions in the different groups of women is nearly identical to that observed in women and men pooled together. This seems to rule out the possibility that the reduced prevalence of lesions in CPAF-positive group might be accounted for by the increased percentage of women in that group. 
culopathy. In addition, the prevalences of abnormal electrocardiograms and oscillograms are significantly higher in non-flushers. These differences in the prevalence of severe lesions cannot be accounted for by obvious differences in the composition of the patient groups, because the mean age and duration of diabetes were not significantly different between 'true' flushers and non-flushers. The aspecific flushers had had slightly longer mean duration of illness, which may explain their higher prevalence of lesions. Apparently this group is not protected against complications, as compared to non-flushers.

This study of a large number of patients has also allowed us to evaluate the incidence in our population of a number of variables which might affect the outcome of the CPAF test. Recently, positive responses in the test have been atributed to previous chronic treatment with chlorpropamide, with a very low incidence in non insulin dependent diabetics treated by diet alone ${ }^{10}$. None of our patients was previously treated with chlorpropamide, and the 'true' flushers were present equally in the two groups of patients on diet and in those treated with oral agents. Unlike PYKE ${ }^{24}$, we failed to observe an increased frequency of family history of diabetes in CPAF positive patients; the high occurrence of dominantly-inherited 'Mason type' diabetes in the population studied by Pyke might explain its higher prevalence.

We have also evaluated whether metabolic or hemostatic parameters be. have differently in relation to the CPAF phenomenon. The association between high levels of triglycerides and cholesterol and a higher risk for developing macroangiopathy has been clearly demonstrated in diabetics $1 ., 14,25$. Although the significance of hemostatic factors in diabetics is controversial, a number of studies has shown that $\beta \cdot \mathrm{TG}^{*}$, VIII:C and fibrinogen ${ }^{*}$ and VIII $\mathrm{R}: \mathrm{Ag}^{21}$ are increased in complicated diabetes. Therefore, the availability of a group of patients protected against the development of severe vascular lesions seemed to give us an opportunity to investigate the role of lipid and hemostatic variables in the generation of these complications.

Our observations, however, failed to shed any light on this point, be cause none of the lipid and hemostatic variables was significantly different in the groups of diabetics subdivided according to their behavior in the CPAF test. These findings suggest that either these variables are not primarily involved in the development of the complications, their abnormalities in diabetes being secondary to the metabolic derangement, or that the mechanism of protection in CPAF-positive diabetics works through other routes.

Glycosylated hemoglobin as far as it does represent the metabolic control did not show differences among groups. We would also like to stress the fact that $\mathrm{HbAl}$ does not give any information about metabolic control during the several years of illness of our patients and could not account for differences in prevalence of lesions.

The observed differences in sex distribution with a female-increased percentage in the flushers (either aspecific or 'true' flushers) raise the question whether a sex-linked factor might explain the different distribution of le. sions. In fact, we tried to consider separately the prevalence data obtained from the 'true' flusher women and to compare them with those obtained from non-flusher women without finding changes from the results obtained with the pooled data (tab. 4). It should be also considered that the aspecific flushers were prevailingly women (69\%) and showed, nevertheless, increased 
prevalence of lesions. We feel therefore that the possibility that the different prevalences of lesions are to be ascribed to sex distribution can be ruled out.

Finally, we are aware that other risk factors may be claimed for vascular lesions and among them smoking. Only 18 out of our 108 patients were smokers, quite equally divided in the different groups, and only 9 of them smoked more than 10 cigarettes per day. It was therefore impossible to dis. criminate a specific effect of smoke.

In conclusion, we confirm the lower prevalence of vascular lesions in the CPAF positive patients when the aspecific flushers are eliminated by a placebo test. The discordant reports concerning the percentage of positive patients may be due to the lack of objective means for judging the positiveness or to differences in the populations of diabetics. The large scale epidemiological study and the unification of procedures recently announced by JEFFERYs et al. ${ }^{\text {is }}$ must therefore be completed before we can use the CPAF.test for genetic counseling and prognostic labeling in non insulin-dependent diabetics.

\section{SUMMARY}

One hundred and eight non insulindependent diabetics were tested for alcohol flushing after chlorpropamide administration (CPAF test). The overall prevalence of partents who flushed at the first challenge was $32 \%$. However, nearly half of them still flushed after alcohol administration. when placebo was given instead of chlorpropamide, so that the prevalence of 'true' flushers was only 17\%. Even though the distribution of retinal lesions was similar in 'true' lushers and in non Rushers, severe loss of visual acuity was confined to the non flushers and aspecific flushers. The frequency of parhological ECG findings and of peripheral pulse reduction or abolition was significantly higher in the non flushers and aspecific flushers. Blood pressure, serum lipids and hemostatic parameters were similar in the rwo groups, and therefore do not explain the differences in prevalence of lesions. This study confirms the pre. vious findings of a lower prevalence of large vessel lesions in flushers; however, the preva. lence of 'true' CPAF phenomenon in our out pacient population appears to be much lower than previously reported.

\section{ACKNOWLEDGEMENTS}

We thank Prof. A. Fasoli for helpful discussion and revision of the paper. We wish to ac. knowledge the skillful nursing assistance of Mrs. Rosa Zanotti and Mrs. Wanda Caranzi.

\section{REFERENCES}

1. Albrink M.J., Lavietes P. H., Man E. B.: Vascular disease and serum lipids in diabetes mellitus. Observations over thinty years (1931.1961) Ann. intern. Med. 58, 305. 1963.

2. Babsoy H. L., Shapiro P. O.. Philips G. E. A new assay for cholesterol esters which is not affected by bilirubin . Clin. chim. tcta 7, 800, 1962.

3. BARNeTT A. H., PYKe D. A.: Chlonpropanide-alcohol flushing and langevessel disease in non-insulindependent diabetes - Brit. med. J. 2, 261, 1980.

4. Bolton A. E., Ludlam C. A., Moore S., Pepper D. S. CAsh J. D.: Three approaches to the radioimmunoassay of human B.thromboglobulin - Brit. J. Haemat. 33, 233, 1976.

5. BuRstein M. SCholvick H. R.. Morfin R.: Rapjid method for the isolation of lipoproteins from human serum by precipitation with polyanions - J. Lipid Res. 11, 583, 1970.

6. Burrows A. W., Chavin S. 1., Hockaday T. D. R.: Plasma thromboglobulin concentration in diabetes mellitus. Lancet $i, 235,1978$. 
7. Comn P.F., Gabbay S. I. Wrglicki W. B.: Serum lipid levels in angiographically defmed coronary artery disease. Ann. intern. Med. 84, 241, 1976.

8. Coller B. S. Frank R. N., Mhiton R. C., Gralnick H. R.: Plasma cofactors of platelet function: correlation with diabetic retinopathy and hemoglobins $A_{l_{2}}$. Ann. intern. Met. $8.311,1978$.

9. Denson W. W. E: Techniques. In: BtgGs R. (Ed): Human blood coagulation, hemostasis and thrombosis. Blackwell Sci. Publ., Oxtord.Edinburgh, 1976; p. 475

10. De Silva N. E. Tunbridge W. M. G., Alberti K. G. M. M.: Low incidence of chlorpropamide-alcohol flushing in diet-reated, non-insulindependent diabetes. Lancer $i, 128.1981$.

11. Eccsteja M., Kreutz K. H.: Eine neue Bestimmung der Neutralfetre im Blutserum und Gewele. 1. Mitteilung (Prinzip, Durchführung und Besprechung der Methode). Klin. Wischx, \%, $262,1966$.

12. Fitzchald M. G. Gadde R.. Maliss J. M., OSullvain D. J.: Alcohol sensitivity in diabe. tics receiving chlorpropamide- Diabetes 11 : 40, 1962.

13. Friednax H. H. Diagnosi eletrocardiografica e vettocardiografica - Il Pensiero Scientifico Ed. Roma. 1978; p. 234.

14. GANDA O. P.: Pathogenesis ol macrovascular disease in human diabetic. Diabetes 29, 931 . 1980.

15. Jefrers D. B., KeEN H. NG TAvg Fu S. Chlorpropamide alcohol flush - Lancet $i$, 440 , 1981.

16. Kannel. W. B. Castell W. B., Gordon T., MCNandra P. M.: Serum cholesterol, lipopro. teins, and the risk of coronary heart disease. The Framingham study. Ann. intern. Med. $77,1,1971$.

17. Köbberlang J., Bengsch N., Brëcgeboes B. Schwarck H., Tullil H., Weber MI: The chlor propamide alcohol flush. Lack of specificity for familial non-insulin dependent diabetes. Diabetologia $19.359,1980$.

18. LAtirel C. B.: Electroimmunoassay - Scand. J. clin. Lab. Invest. 29 (Suppl. 124). $21,1972$.

19. Lesle R. D. G., Barnett A. H., Pyke D. A.: Chlorpropamide alcohol thushing and diabetic retinopathy - Lancet $i, 997,1979$.

20. LesLte R. D. G., PYke D. A.: Chlorpropamide alcohol flushing: a dominanty inherited trait associated with diabetes. Brit. med. J. 2. 1.519. 1978.

21. LLFKIN E. G., FASS D. N., OFALLON W. M., BOWIE E. J. W.: Increased von Willebrand factor in diabetes mellitus - Netabolism 28,63, 1979.

22. Micossi P.: The prevalence of chlorpropamide alcohol flushing in non-insulin dependent diaberics-Diaberologia 20,510, 1981 .

23. Natronal Diabetes Dara Group: Classification and diagnosis of diabetes mellinus and orher categories of glucose intolerance - Diabetes 2S, $1039,1979$.

24. Pyke D. A.: Diabetes: the genetic connections - Diabetologia 17, 333, 1979.

25. SChonfeid G., Birge C. Miner J.P., Kesiler G. SAntiago J.: Apoliprotein B levels and altered lipoprotein composition in diabetes - Diabetes 23,827, 1974.

26. Vermylex C., DE VREker R. A., Verstraete M.: A quick quantiative enzymalic fibrinogen assay method: the fibrin polymerization time (FPT) Clin. chim. Acta $8,418,1963$.

Requests for refuints should be addresied to:

PIERO Micossi

Clinica Medicn WhI dell'Unintrosita

Ospedale S. Raffaele

Via Olgettina 00,20100 Milano - Italy 